\title{
BCL-6 Corepressor-Like Protein 1
}

National Cancer Institute

\section{Source}

National Cancer Institute. BCL-6 Corepressor-Like Protein 1. NCI Thesaurus. Code C131270.

BCL-6 corepressor-like protein 1 (78 aa, $183 \mathrm{kDa}$ ) is encoded by the human BCORL1 gene. This protein plays a role in the repression of gene transcription. 